\title{
6 \\ Conflict, Convicts and the Condominium
}

Everyone knows that 'La Nouvelle', as it is popularly called, is a French penal settlement, and thereby hangs a tale. ${ }^{1}$

It was September 1905. The Anglo-French Convention, so Australians hoped, would get to work on the New Hebridean question almost immediately ... Altogether, the New Hebrides were providing much food for talk and guesswork. It was an odd fact, under the circumstances, that no one really knew anything to speak of about the place. ${ }^{2}$

The French colonial presence in New Caledonia and the New Hebrides meant that Australian representations of these two Island groups would be distinct from any other Pacific Islands. In contrast to French Polynesia and Tahiti-which were represented as ideal, romantic and remote destinations-New Caledonia and the New Hebrides were widely perceived as posing an imminent threat to mainland Australia in the late nineteenth and early twentieth centuries. Australian travel accounts of these Islands were markedly different from those of British and French literature because they reflected national anxieties and fears that were felt about French colonial rule from 1880 to 1914 . As suggested by the two quotations at the beginning of this chapter, provided by two Australian travellers in 1906 and 1907, respectively, Australians were preoccupied with French convicts in New Caledonia and in the joint Anglo-French

Wragge, The Romance of the South Seas, 3.

2 Grimshaw, From Fiji to the Cannibal Islands, 166. 
political system in the New Hebrides. Although public interest in these Island groups peaked in the late nineteenth century, travel accounts continued to remind Australians of the French colonial legacy in the Pacific until World War I.

Australian representations of New Caledonia and the New Hebrides were marked by three main themes: conflict, convicts and the condominium. These themes were not mutually exclusive; rather, they overlapped and reappeared in the travel accounts of colonial Australians from the late nineteenth century and in the accounts of Australian nationals from the early twentieth century. Since the 1870 s, colonial Australians were aware that New Caledonia and the New Hebrides were more closely tied by steamship routes - not only in the physical sense but also politically, economically and culturally. As such, colonial Australian observations of conflict between French settlers and Islanders in New Caledonia in the nineteenth century reflected greater concerns about the legitimacy of French colonial rule in the New Hebrides. Convicts were another persistent theme in New Caledonia, but how they were portrayed shifted from a perceived threat in the nineteenth century to a historical attraction in the twentieth century. This reflected New Caledonia's increasing popularity as a tourist destination for Australians by the early 1900s. Although convicts and conflict were clearly associated with New Caledonia, travellers' descriptions of the New Hebrides were more ambiguous. Their reactions to the joint Anglo-French condominium were characterised by confusion and uncertainty due to the diverse nature of the Island group, as well as the unresolved nature of the agreement. These sentiments existed despite the increasing number of travellers to the region and the widespread publicity of the expansion of French interests in New Caledonia and the New Hebrides. Since Australian interest in these Islands had significantly diminished by World War I, Australian travel accounts offer the most significant insights into the period from the 1870s to the 1910s. They are presented here in a loosely chronological order, commencing with French colonial rule in New Caledonia, then its rule in the New Hebrides and concludes with a discussion of tourism development in Noumea in the early 1900s. 


\section{Conflict and Convicts in New Caledonia}

Situated only 1,500 km east of the Australian coast, New Caledonia was of great public interest to the Australian colonies in the mid to late nineteenth century. However, limited travel writing about it before 1900 exists. Of the 19 accounts that have described travels to New Caledonia, three were published between 1880 and 1899, nine between 1900 and 1914 and seven between 1915 and 1941. Although New Caledonia may not have been the preferred holiday destination at this time, it had sustained contact with colonial Australians from the 1840s. This was mostly done in the form of the sandalwood and bêche-de-mer traders, LMS and Marist missionaries. ${ }^{3}$ Colonial Australians also travelled to New Caledonia as labour traders, though New Caledonia was a site for deploying rather than recruiting labour. The systematic recruiting of labour for New Caledonia began in 1865 to help develop the colony, with most of these recruits drawn from the New Hebrides, Solomon Islands and Gilbert Islands. Some indigenous people from New Caledonia travelled as ships' crews, with Loyalty Islanders possessing a positive reputation among Europeans as seamen. ${ }^{4}$ The mining industry's development encouraged the continuation of the labour trade to extend beyond the 1940s, as well as to support British and Australian prospectors and entrepreneurs (though the scale of settlement was limited).

It was not until the 1880 s that a regular steamship service brought more colonial Australians into contact with New Caledonia. From 1882 onwards, French-owned MM operated a service between Sydney and New Caledonia's main port, Noumea. This was followed by a service provided by AUSN from 1887. Noumea was often a layover port on the journey to the New Hebrides, stimulating comparisons in colonial Australian travel accounts between the two Island groups. Few travellers went beyond the mainland (Grand Terre) to visit nearby Islands such as the Loyalty Islands or the Isle of Pines.

3 Dorothy Shineberg, They Came For Sandalwood: A Study of the Sandalwood Trade in the South-West Pacific, 1830-1865 (Melbourne: Melbourne University Press, 1967); Dorothy Shineberg, The People Trade: Pacific Island Laborers and New Caledonia, 1865-1930 (Honolulu: University of Hawai'i Press, 1999), 11-12, doi.org/10.1515/9780824864910.

4 For examples, see Thomas, Cannibals and Convicts, 147; Wragge, The Romance of the South Seas, 33. 
Since its annexation in 1853, the French occupation of New Caledonia was widely perceived within the Australian colonies as a potential strategic threat to the Australian mainland-which was a view encouraged by sensationalised and speculative media reports. This concern was exacerbated by the commencement of penal resettlement to the French territory in May 1864; it fostered further antagonism in the Australian colonies, which fed into the growing federation movement from the $1880 \mathrm{~s}$. Alexis Bergantz's historical study of French-ness in Australia identified the important role that New Caledonia played in the development of a national consciousness in the Australian colonies - a point, he argued, that has been overlooked in favour of other imperial rivalries. ${ }^{5}$ Public record reveals that New Caledonia was a popular issue of debate at the time, as journalist Frank Fox noted in 1911: 'One result of the existence of this French penal settlement in New Caledonia was to hasten the growth of Australian Federal sentiment'. ${ }^{6}$ The popularity of invasion narratives in the late nineteenth century also encouraged the idea that New Caledonia could be used as a staging ground for invasion. ${ }^{7}$ The hostile public response was distinct from the benign reactions to the establishment of other French colonies-including those to the annexation of Tahiti in 1880 , followed by those to the Gambier, Austral and Tuamotu groups in 1881 and to the creation of protectorates over Wallis and Futuna in 1886. Not only was French Polynesia beyond the Australian colonies' sphere of interest, it was also not as developed nor as highly populated by the French.

Colonial Australians' travel writing about New Caledonia in the 1880s and 1890s is marked by a general theme of conflict that reflected greater concerns. Conflict was often predicted, and occasionally observed, between several parties: the Australian colonies, the French and British governments, French colonial administrators, missionaries, convicts and the indigenous people. Travellers frequently and interchangeably used the Hawaiian term 'kanaka' and the New Caledonian term 'kanak' to describe the indigenous people. Australian journalist John Stanley James wrote extensively about his travels in New Caledonia in the 1870s and 1880s. His commentary offers glimpses into the colonial Australian perceptions that were prevalent in the public sphere during this time.

5 Alexis Bergantz, 'French Connection: The Culture and Politics of Frenchness in Australia, 18901914' (PhD thesis, The Australian National University, 2015), 56.

6 Fox, Oceania, 17.

7 Bergantz, 'French Connection', 63. 
Born in England in 1843, James moved to Australia in 1875 when he became moneyless due to wandering across Europe and the US as a self-styled 'vagabond' and journalist. He began working for the Melbourne Punch, then for the Argus in 1876, writing under the pseudonyms of 'Julian Thomas' and 'the Vagabond'. James's popularity peaked at the end of 1876, partly due to a public fascination with his anonymity, as well as the resonance that his subject matter had with the colonial Australian middle class. ${ }^{8}$ James made several trips to the Pacific Islands, which were sponsored by local newspapers, including a trip in 1878 to report on indigenous rebellions against French colonial rule in New Caledonia. His observations were widely circulated in newspapers and in his own publications, such as the travelogue Cannibals and Convicts (1886). Consequently, James's impressions of the Pacific Islands were a mix of journalistic reporting and personal narrative. James's travelogue was unillustrated, most likely due to the limitations of photographic technology at the time. However, he was visually represented inside the cover among a series of key protagonists in Pacific politics at the time.

In his self-published materials, James described himself as a journalist 'first and foremost', proudly claiming to be the only reporter to visit New Caledonia and the New Hebrides in 1886. He alleged that he was one of:

That noble army of Special Correspondents who, taking their lives in their hands, amidst battle, murder, and sudden death, provide[d] not only news, but solid information, for the breakfasttables of the world. ${ }^{9}$

Although James professed a desire to be impartial, he often had to negotiate the demands of his sponsors, choosing at times to oppose the popular views among specific editors and readerships. This included criticising British rule in Fiji in 1880 and defending the methods of Australian recruiters in the New Hebrides. His biographer, Michael Cannon, described his views as being 'liberal, conservative, free trade and anti-church'. ${ }^{10}$ James's popularity and authority entailed that his reports were influential in informing colonial Australians about New Caledonia at

8 Michael Cannon, 'Introduction', in The Vagabond Papers, ed. Michael Cannon (Melbourne: Hyland House, 1983), 5. In previous chapters, I have referred to James by his own chosen pseudonym. However, in this chapter, I will refer to him as 'James' in the text and by his chosen pseudonym in the footnote.

9 Thomas, Cannibals and Convicts, vii.

10 Cannon, 'Introduction', 5. 
a time when public interest in the group peaked. His role was particularly significant, given the limited number of existing travel accounts on the topic of New Caledonia in the late nineteenth century.

James detailed his travels to New Caledonia in 1878 and 1883 in Cannibals and Convicts, parts of which were published in the Australasian and Melbourne Argus. He had also mentioned his travels to Fiji, the New Hebrides and New Guinea, with a conclusion that described his views regarding Australian Federation and colonialism in the Pacific. Sailing on the Gunga from Sydney on 20 July 1878, James made the following remark after arriving in Noumea: 'New Caledonia is a land of the gum-tree and the convict; but there its similarity to early Australia ceases' ${ }^{11}$ His account was typical of many subsequent travel accounts that immediately characterised the Island as a penal settlement. His remarks noting the Island's geographical proximity to Australia, its resources (he identified mining as valuable) and its history of contact with Europeans were also repeated in other colonial Australian accounts. These observations not only informed but subtly conveyed a sense of conflict and antagonism between the French and the Australian colonies. For example, a school textbook in 1888 educated colonial Australians about Captain Cook's discovery of New Caledonia in September 1774 and about the 'unjust' nature of French annexation on 24 September 1853, which was similar to James's assertion of Great Britain's claim by 'right of discovery'. ${ }^{12}$ Although James felt no open hostility after arriving (noting the helpful assistance that the French authorities offered to him), a certain tension was evident. He reported that his telegrams home were suppressed by the French, who restricted him from publishing his accounts until his return.

When James arrived in 1878, the tension between French settlers (who had arrived in growing numbers since annexation) and the Kanaks (whose land they had alienated) exploded, led by a significant chief named Atai. Historians have since revealed that European representations of this conflict that occurred between French colonial masters and Kanak resistance were not accurate. Rather, political alliances in New Caledonia

11 Thomas, Cannibals and Convicts, 46.

12 William Wilkins, Australasia: A Descriptive and Pictorial Account of the Australian and New Zealand Colonies, Tasmania and the Adjacent Lands (London: Blackie \& Son, 1888), 236; Thomas, Cannibals and Convicts, 47. 
were much more complex. ${ }^{13}$ For audiences in the Australian continent who were curious about their colonial neighbours, the 1878 rebellion was but one of a series of well-publicised conflicts since 1856 that was oversimplified in the press as a struggle between French civilisation and Melanesian savagery.

In general, James provided a damning account of French colonial rule during his visit to New Caledonia. Sent to report on the so-called 'native insurrection' in New Caledonia, James arrived one month after the French governor, Jean Baptiste Léon Olry, announced the outbreak of war. His first impressions of Noumea described French residents and officials, but Kanaks were not visible in the capital, despite numbering 60,000, as estimated by James. ${ }^{14}$ He was transported from Noumea with French soldiers to one of four fronts at Bouloupari. Over several months, James studied 'how France treats a native population', which involved observing French military tactics, accompanying patrols, visiting local villages of both French settlers and Kanaks and meeting Kanak chiefs and French military commanders.

James portrayed the ongoing conflict as a bloody battle 'with over 200 [French] massacred in one week' - with even more deadly reprisals by the French and evidence of casualties on both sides. ${ }^{15}$ In his reporting of the revolt, James noted the French side's poor military tactics and lack of knowledge of the interior. This assessment was accurate, given that French settlement and exploration of the northern inland areas were limited before the conflict. ${ }^{16} \mathrm{He}$ was also critical of the brutality and unprofessionalism that French forces displayed, describing how French soldiers destroyed houses and crops and killed people indiscriminately and without trial: "Man, woman, and child must be exterminated," was the cry of most of the gallant soldiers of France ... It seemed to me that nearly

13 See Bronwen Douglas, 'Conflict and Alliance in a Colonial Context', The Journal of Pacific History 15, no. 1 (1980): 21-51; Bronwen Douglas, 'Winning and Losing? Reflections on the War of 1878-79 in New Caledonia', The Journal of Pacific History 26, no. 2 (1991): 213-33, doi. org/10.1080/00223349108572664; Bronwen Douglas, 'Fighting as Savagery and Romance: New Caledonia Past and Present', in Reflections on Violence in Melanesia, ed. Sinclair Dinnen and Allison Ley (Leichhardt: Hawkins Press, 2000), 53-64; Linda Latham, 'Revolt Re-Examined: The 1878 Insurrection in New Caledonia', The Journal of Pacific History 10, no. 3 (1975): 48-63, doi.org/ 10.1080/00223347508572278; Adrian Muckle, Specters of Violence in a Colonial Context: New Caledonia, 1917 (Honolulu: University of Hawai'i Press, 2012).

14 Thomas, Cannibals and Convicts, 42.

15 Thomas, Cannibals and Convicts, 48.

16 Douglas, 'Conflict and Alliance', 41. 
everyone in Noumea was mad'. ${ }^{17}$ In one case at Teremba, James described the death of five Kanaks, including a 13-year-old boy, by firing squad without trial for the alleged murder of an ex-convict. James described the trial and subsequent execution of the men as 'an act illogical, unjust, and useless in its results [which] ... to my dying day they will haunt me'. ${ }^{18}$ These observations, which highlighted the brutality of French colonial rule, were repeated by a colonial Australian mining prospector who wrote under the pseudonym 'Gunga'. He witnessed 'frightful heartrending scenes' during the 1878 rebellion and blamed the French in the conclusion to his travel account: 'If I was asked what brought about the revolt I should say ill treatment, unfair treatment, unjust treatment of the natives, by the Government and by the settlers themselves'. ${ }^{19}$

James' representation of the Kanaks was more ambiguous; he sympathised with those who supported the French and portrayed the others as conventional savages and cannibals. By admiring the physical characteristics of the Kanaks whom he met in French-controlled camps and villages, James contrasted them to the savage behaviours of the French settlers and soldiers. When travelling inland with Kanak guides who were assisting the French, James described them as a 'picturesque sight', and when meeting some chiefs at a French camp, he remarked:

Naked and not ashamed, their supple, lithe, well-proportioned figures were beautiful to look upon. I have seen many a dusky warrior, whose form would have served the Grecian sculptor of old as a model for Apollo. ${ }^{20}$

However, other descriptions of beheadings, ambushes and people whom he claimed were 'as ugly a "nigger" as you could find in the world' betrayed James's deeply held conservative and racist views of Pacific Islanders being inferior. ${ }^{21}$ Although he acknowledged the confusion of guerrilla warfare in the New Caledonian theatre, his observations of Melanesian fighting tactics being cowardly and primitive were consistent with other European descriptions. Bronwen Douglas and Adrian Muckle have since demonstrated the soundness of guerrilla tactics that the Kanaks used to resist French rule. ${ }^{22}$

17 Thomas, Cannibals and Convicts, 79.

18 Thomas, Cannibals and Convicts, 89-93.

19 Gunga, Narrative of a Trip from Maryborough to New Caledonia, 5.

20 Thomas, Cannibals and Convicts, 105, 197.

21 Thomas, Cannibals and Convicts, 21, 25.

22 Douglas, 'Conflict and Alliance'; Muckle, Specters of Violence. 
Although news of the 1878 insurrection was highly publicised in the Australian colonies and contributed to notions of Melanesian savagery and French incompetence, a more serious threat was perceived in the convicts who were sent to New Caledonia. Colonial Australians had been opposed to the transportation of French convicts since the first convoy of 248 bagnards arrived in 1864 . However, the expansion of the penal colony to accommodate convicted reoffenders reignited opposition in the 1880s. These criminals were especially feared in the Australian colonies, with James having described the recidivist as 'an outlaw of society, the scum which floats on the surface of civilisation'. ${ }^{23}$ James highlighted the danger that the bagnards and recidivists posed by attributing them characteristics that were usually used for Melanesians: 'Thinking of the combined convict and cannibal Pierre, I was forced to the conclusion that New Caledonia sheltered a large number of most objectionable neighbours to Australia'. ${ }^{24}$ James argued that convicts in such close proximity to the Australian continent would be considered a threat for two reasons:

Here, on the island of [île] Nou, one reflected that the danger to Australia was not only in the escape of the convicts (and scores have escaped and landed on our shores), but in the use to which they might be put in time of war ... It may be said that France would hardly arm her convicts against Australia; but all is fair in love and war. ${ }^{25}$

Sensationalised press reports inflamed these concerns, with reports on escaped convicts reaching the Australian mainland and suggestions that the New Hebrides could become another penal settlement.

Realistically, the French threat to Australian security was overstated. Although several prisoners did escape to the Australian mainland, most who reached the shore had already served their terms or had been pardoned. Robert Aldrich argued that few, if any, posed any real threat to the Australian colonies. ${ }^{26}$ Migration was even encouraged by ambiguous French laws regarding emancipists. These libérés, who were unpopular in New Caledonia and who struggled to find employment, were allowed to leave New Caledonia, provided that they did not return to France and

23 Thomas, Cannibals and Convicts, 144.

24 Thomas, Cannibals and Convicts, 113.

25 Thomas, Cannibals and Convicts, 120-1.

26 Robert Aldrich, The French Presence in the South Pacific, 1842-1940 (Basingstoke: Palgrave Macmillan, 1990), 225. 
that they returned to the colony only after three years. ${ }^{27}$ Additionally, the number of French-born residents in the Australian colonies was relatively small, and their European background allowed them to assimilate within the community easily. Therefore, they did not constitute a threat as much as other more populous and non-white ethnic groups were perceived to. ${ }^{28}$

Due to James's travels, extensive publications and public reputation, he became an influential observer of New Caledonian affairs. His criticisms of French colonial expansion in the Pacific reflected broader colonial Australian public sentiment in the 1880s and 1890s. By drawing on conventional notions of Melanesian savagery and contributing to public hysteria regarding escaped convicts, James attacked the legitimacy of French colonial rule in New Caledonia. His observations, along with the subsequent impressions of Australian travellers, formed part of a more urgent argument that opposed French annexation of the New Hebrides. Further reading of travel writing that pertains to New Caledonia, whose French ownership was largely uncontested, should be reinterpreted in light of these broader concerns about the New Hebrides and their unresolved political status.

\section{Contesting French Rule in the New Hebrides}

Like New Caledonia, Australian travel writing about the New Hebrides was limited due to the nature of steamship routes. Consequently, the small number of reports available does not accurately reflect the high level of public anxiety felt in regard to this Island group. Four travel accounts about the New Hebrides were published between 1880 and 1899, seven between 1900 and 1914 and six from 1915 to 1941. Regular steamship routes to the New Hebrides were provided by BP from 1896 and by MM from 1901 to service the growing number of white settlers. Unlike New Caledonia, the New Hebrides were further away and contained more islands. Even in 1908, BP employee Wilson le Couteur described the monotonous journey of BP's inter-island steamer, Tambo, which anchored

27 Isabelle Merle, 'The Trials and Tribulations of the Emancipists: The Consequences of Penal Colonisation in New Caledonia 1864-1920', in France Abroad: Indochina, New Caledonia, Wallis and Futuna, Mayotte: Papers Presented at the Tenth George Rude Seminar, ed. Robert Aldrich and Isabelle Merle (Sydney: University of Sydney, 1997), 42.

28 Aldrich, The French Presence in the South Pacific, 199. 
103 times over 33 days in the New Hebrides. ${ }^{29}$ One tourist, Joseph Hadfield Grundy, declined a round trip of the Island group because the vessel Induna was 'not a floating palace', being 'infested with rats, mice and cockroaches'. ${ }^{30}$

Colonial Australians were familiar with these Islands due to the labour trade that recruited Islanders from the New Hebrides for Queensland's sugar plantations from the 1860s. This trade was strongly opposed by the Presbyterian Church, which was most powerful in Victoria. Led by Reverend John Gibson Paton in the late nineteenth century, the Presbyterians mobilised opposition to the labour trade in Melanesia and to that of French colonial ambitions in the New Hebrides, engaging public debate in both the Australian colonies and England. Presbyterians found support among some colonial Australian traders and farmers in the New Hebrides, as well as from the Argus and the Age, to push for annexation in the 1870s and 1880s. They also took advantage of the fear that the New Caledonian penal settlement would be expanded to the New Hebrides. ${ }^{31}$ Ultimately, the Australian colonies and the British government were reluctant to bear the cost of extending the empire or possibly aggravating other colonial powers.

Several events in the 1880 s contributed to a popular perception of British antipathy towards the region, as well as strengthened calls for Australian annexation and imperialism in the Pacific. This included the unopposed German annexation of north-eastern New Guinea in 1884 and the diplomatic crisis involving the New Hebrides in 1886. This crisis was precipitated by Britain's decision not to accept the 1883 proposal for French annexation of the New Hebrides in exchange for another Pacific Island, Rapa, and an agreement by the French to stop sending convicts to New Caledonia. ${ }^{32}$ Presbyterian minister Charles Stuart Ross described the French response as openly hostile:

In September $1886 \ldots$ the French Republic, thirsting for Colonial expansion, having exhausted the resources for diplomacy to acquire possession of the New Hebrides, made a bold stroke for annexation by landing a body of troops at Havannah

29 Wilson le Couteur, 'The New Hebrides. Development at Vila. Copra and Cotton. Aneityum Depopulated', Sydney Morning Herald, 1 September 1908, 10, nla.gov.au/nla.news-article15021942.

30 Grundy, The New Hebrides Group of Islands, 7.

31 Thompson, Australian Imperialism in the Pacific, 44-5.

32 Aldrich, The French Presence in the South Pacific, 229. 
Harbour, with the purpose of seizing by force a tract of land the proprietary right to which was in dispute between certain French and British settlers ... a temporary agreement was arrived ... And Mr. Thurston [Acting British High Commissioner], who knew the value of the Islands to the Australian Commonwealth, and keenly watched every movement that aimed to alienate them from British influence and control, addressed a strong protest on the subject to the Victorian premier. ${ }^{33}$

Consequently, a joint Anglo-French naval commission was created in 1887. This event was widely remembered and repeated by subsequent travellers to the New Hebrides. James went as far as to publish a petition to the Queen, signed by the chiefs of Tanna, and to criticise the inaction of England:

Great Britain should give a proof of their desire to aid us. We called out loudly against the German acquisition of territory near our shores. We still call out loudly against the further extension of the French possessions in the Western Pacific. ${ }^{34}$

Due to these colonial tensions, Luke Trainor argued that Australian interest in the Pacific reached its peak at this time, which is evident in newspaper coverage and regular public demonstrations. ${ }^{35}$

In response, the Australian colonies began subsidising shipping services by USSCo. and AUSN from Sydney and Melbourne to the New Hebrides. They also supported the formation of the ANHC in 1889, of which BP was a major investor. This was a joint venture created by several companies, prominent businessmen and politicians who considered settlement a key to gaining a foothold in the New Hebrides. ${ }^{36} \mathrm{BP}$ and ANHC consistently lobbied for the support of British and Australian interests in the New Hebrides, including shipping subsidies on which they relied. A brochure printed by the ANHC argued that these subsidies were vital for supporting 'flourishing Australian interests' in the group and for protecting it from 'jealous foreign powers'-specifically, the French 'menace to Australian peace and progress'. ${ }^{37}$ Businesses promoted the New Hebrides as

33 Ross, Fiji and the Western Pacific, 169.

34 Thomas, Cannibals and Convicts, 406.

35 Trainor, British Imperialism and Australian Nationalism, 18.

36 Roger C Thompson, 'Commerce, Christianity and Colonialism: The Australasian New Hebrides Company 1883-1897', The Journal of Pacific History 6, no. 1 (1971): 25, doi.org/10.1080/00223347 108572181.

37 Australasian New Hebrides Company, Australia and the New Hebrides, 2-3. 
a commercial haven that awaited the heroic Australian trader or planter. This self-promotion was particularly important during the 1890s, when public interest in the New Hebrides began to wane despite the continued efforts of the Presbyterian Church and the Victorian government to push for annexation. ${ }^{38}$

Although the ANHC ultimately collapsed in 1897, BP continued its commercial ventures in the region. It positioned itself as a national institution and encouraged nationalistic narratives about the New Hebrides in the twentieth century. The effect of this promotion is evident in Beatrice Grimshaw's 1905 newspaper article in the Sydney Morning Herald:

To the outsider coming from far-away Britain, it seems as though France and Burns, Philp were politely disputing the ownership of the New Hebrides, rather than France and Australia. Burns, Philp is the general providence of the islands - rebelled against at times, as general providence and managers usually are; told flatly that it does not give value for its subsidy; that its freights must be lowered; that it does not do this, and ought not to do the other; but, nevertheless, clung to by the British element as its useful and true, though faulty, ally. ${ }^{39}$

It is unclear whether Grimshaw's remarks were part of a paid promotion, but Kenneth Buckley and Kris Klugman's history of BP suggests that the company was generally considered the Australian government's representative in the New Hebrides by the early $1900 s^{40}$

The turn of the century prompted renewed public debate about the New Hebrides. The newly federated nation of Australia responded by continuing official efforts to subvert French interests in the New Hebrides, including economic subsidies and even sending a spy. Wilson le Couteur was Australia's first official spy, travelling under the guise of a BP employee in the New Hebrides for three months in 1901. His report was released anonymously in the Age. ${ }^{41}$ Although the ANHC settlement schemes of the 1890s had collapsed, negotiations regarding the naval commission reignited notions about Australian annexation, until an

38 Thompson, Australian Imperialism in the Pacific, 140.

39 Beatrice Grimshaw, 'Life in the New Hebrides', Sydney Morning Herald, 25 November 1905, 6, nla.gov.au/nla.news-article14734425.

40 Buckley and Klugman, The History of Burns Philp, 105-6.

41 Thompson, Australian Imperialism in the Pacific, 167. 
Anglo-French condominium was agreed upon in 1906. Once signed, the agreement ended any possibility of Australia totally acquiring the group. Concurrently, the number of visitors to the Island group increased significantly - many of whom were attracted by the tourist cruises that were offered—and produced more travel writing in the process.

Most travellers knew the origins of the condominium at this time, with many of the accounts that were written between 1900 and 1914 offering a historical overview or commentary on the history of France's disputed claim to the New Hebrides. In 1915, self-described tourist J Mayne Anderson remarked that 'having recently read [Edward] Jacomb's book and various newspaper reports on the much vexed condominium questions, we were naturally curious to reach Vila'. ${ }^{42}$ In 1901, while on a seven-week cruise, Richard Cheeseman described his trip as 'enjoyable and instructive'. ${ }^{43}$ It confirmed his belief in Australia's claim to the Island group:

Australia has, in the short interval of 50 years, become a power to be reckoned with, a voice that commands attention, and were we 50 years farther on, any dispute about who should possess the New Hebrides would not remain unsettled for long. ${ }^{44}$

Grimshaw's account in 1907 was more alarmist, warning her Australian readers that:

For us, it means that the loss of our rights would place a hornet's nest belonging to a foreign power at the gates of our most important, and least effectively defended, colony [Papua]. ${ }^{45}$

Grimshaw lobbied strongly for British rule in the New Hebrides, citing the success of the nation's colonial record in the Solomon Islands.

However, obtaining evidence of the merits or faults of the condominium was much more difficult in the capital of Vila. Apart from the novelty of Vila's combined French and British influence, visitors' accounts resemble those of other Islands. They admired the harbour and panoramic views from higher ground and described the colonial buildings and layout of the town. In Anderson's case, he expressed his reluctance to make any comment about the condominium at all in 1915, noting that:

42 Anderson, What a Tourist Sees in the New Hebrides, 9.

43 Cheeseman, The South Sea Islands, 17.

44 Cheeseman, The South Sea Islands, 6.

45 Grimshaw, From Fiji to the Cannibal Islands, 177-8. 
A few tourists are let go on a long-suffering island people, who have their hospitality returned by criticism of their method of government. A bad feeling is created on one side or other, and certainly no good results in any case. ${ }^{46}$

Such an ambivalent stance may have reflected the political sensitivity of the issue at a time when Australia was France's ally in World War I. Although Australians were generally critical of French rule, their accounts were also ambiguous about whether Britain, Australia or a combination of both governments should be the replacement. ${ }^{47}$

If evidence of the condominium's workings was elusive in the capital, then travellers searched for it during the numerous short stops of the inter-island steamer. Anderson's account revealed that by 1915 , locals were catering to the tourist trade. He noted that the villages were cleaned in anticipation of the steamer's arrival and that Islanders sold curios, acted as guides and were familiar with being photographed..$^{48} \mathrm{~A}$ common element of the tourist experience was an encounter with a white resident who would usually act as a guide on the Island. This is evident in the details that travel accounts used to describe these encounters, often giving a voice to residents' complaints about the condominium. Anderson's meetings highlight the diverse encounters that travellers could have with Europeans in the New Hebrides: he met several missionaries and visited the Presbyterian missionary training college; he met an Australian sheep farmer and visited cotton, rubber and timber plantations; and he met scientific researchers, dining with New Zealand academic Professor Macmillan Brown and travelling with an ethnology student. Australian travellers were as likely to meet French residents as they were to meet British people, with these encounters not necessarily being hostile as expected.

Given the highly publicised settlement schemes and promotions that emphasised the natural resources of the New Hebrides, many Australians were eager to find a trader when they arrived. They were also eager to form their own judgement regarding the success or failure of commerce in the Island group. Visitors' descriptions tend to reflect the day-to-day difficulties of adapting to the condominium, rather than the heroic or patriotic overtones of BP propaganda. Importantly, travellers were often

46 Anderson, What a Tourist Sees in the New Hebrides, 29.

47 Grimshaw, From Fiji to the Cannibal Islands, 181.

48 Anderson, What a Tourist Sees in the New Hebrides, 102. 
unsure where residents' loyalties lay; even during the politically charged context of the 1880s, James described meeting several residents who preferred French rule. ${ }^{49}$ Grimshaw also observed that:

The English or Australian settler often finds his way a hard one, unless need or greed drives him to discard his nationality, and take out French papers of naturalisation ... Their flag [the Union Jack] is an expensive luxury, but they stick to it—generally. ${ }^{50}$

BP's commercial influence did not always benefit European planters and traders in the Islands, as the nickname 'Bloody Pirates' suggested. Grundy observed this attitude during his voyage:

Traders don't seem to mind whether the island is owned by the French or English. It is amusing to watch the effect on any Burns Philp people of a suggestion that the Germans should have the islands! ${ }^{51}$

This suggests that despite the nationalistic rhetoric, traders and planters were just as concerned with profit as they were the major trading and shipping companies.

Australian travellers frequently reported that British restrictions on the trading of firearms and alcohol in the New Hebrides offered an unfair advantage to French traders and residents. For some Australians, such as Grundy, this was represented as a moral policy that distinguished British rule as superior: 'In trading with the natives the French sell them firearms, ammunition and drink, but the English know well these things are not for their good and refuse them'. ${ }^{52}$ However, many residents found this economically detrimental to their own existence, with firearms being particularly useful as items of exchange for acquiring land. Fox's reference guide informed readers that:

There is general dissatisfaction with the New Hebrides arrangement. It is said that the British trader is not allowed fair play in competition with the French, and the British government takes no interest in the affairs of its subjects. ${ }^{53}$

49 Thomas, Cannibals and Convicts, 184, 193.

50 Grimshaw, From Fiji to the Cannibal Islands, 182.

51 Grundy, The New Hebrides Group of Islands, 4.

52 Grundy, The New Hebrides Group of Islands, 3.

53 Fox, Oceania, 36. 
Others preferred the New Hebrides to the Solomon Islands precisely because British regulations could be avoided.

Visiting steamships also created opportunities for residents to bring their grievances to the attention of Australian travellers. In their travel accounts, these visitors observed that local opposition to British labour restrictions was one major issue. The Pacific Islanders' Protection Acts (passed in 1872 and 1875) prohibited the transport of an Islander for employment aboard an unlicensed British vessel. These acts were designed to protect the welfare of the Islanders and were applied to inter-island trading within the New Hebrides; however, it was not illegal for British settlers to employ labourers if they had been recruited by non-British ships, so many residents purchased Islanders from French ships. ${ }^{54}$ The French use of imported Asian labour was also resented by British and Australian residents. Le Couteur remarked that the Javanese are much discussed in the group as the favoured labour to introduce'; he criticised the 'repatriated kanaka from Queensland' for driving labour prices high. ${ }^{55}$ By the 1940s, this opposition had decreased, as shown in M Kathleen Woodburn's account. It identified the French system of indenture in the New Hebrides as superior. She described the 'Tonkinese' labourers as 'numerous, orderly, clean, squat, muscular, Mongolian types', and argued that British plantations 'languish[ed]' because they were 'prohibited from importing the superior coolie labour from the East'. ${ }^{56}$

The rule of law was also frequently appraised by both residents and travellers. Edward Jacomb's book, France and England in the New Hebrides (1914), was widely read and cited in travel accounts. As a British barrister in Vila, Jacomb's criticisms of the condominium (particularly of the joint court) resonated with Australians. Their travel accounts cited incidents that demonstrated the confusing and inconsistent nature of the court system. As zoologist Alan John Marshall explained in 1937:

There is a Gilbertian court of justice maintaining both a French and British judge, with the presiding judge and prosecutor neutral and nominally of Spanish nationality. French residents are subject to French law; Britons to British. ${ }^{57}$

54 Buckley and Klugman, The History of Burns Philp, 61.

55 Le Couteur, 'The New Hebrides. Old Order and New', 8.

56 Woodburn, Backwash of Empire, 76, 285.

57 Marshall, The Black Musketeers, 285. 
The dual system could also be used to an individual's advantage, as a pamphlet for the ANHC argued in 1899:

An employee of the French New Hebrides Co., gave the British man-of-war the information that an Australian settler expected these fire-arms from Sydney, and he actually used the British manof-war to serve his own ends, and force Australian settlers to buy their fire-arms, \&c., from his French Co. ${ }^{58}$

Policing in the New Hebrides was difficult, with a common complaint being that Europeans were unable to maintain law and order among the Islander population. Rather than articulating the reasons why policing was difficult-particularly the legal ambiguities, limited resources and difficult geography_many Australians simply reported residents' anger towards perceived British inaction. James recounted one trader's observation that the French would defend the lives and properties of European settlers while the British would not. ${ }^{59}$ Government agent John Gaggin recalled a similar case when explaining why other nations had established a 'footing in the Western Pacific'. He recalled the swift, official reprisal for the murder of a German trader in Malekula: 'These nations protect their individual subjects-if they deserve it. The English do not. There is the reason in a nutshell. ${ }^{30}$

As well as incorporating popular nationalist and commercial narratives about the New Hebrides, travellers also appropriated the moral tone of mission propaganda; they critically evaluated the role of the missions in the Island group. Australian missions were actively proselytising in the New Hebrides and were crucial for stimulating public debate about the Pacific Islands in Australia. Of these missions, the Presbyterian Church in Victoria was the most vigilant overseer of French abuses in the New Hebrides in the late nineteenth century. It continued to watch over the Island group after public interest had dissipated in the 1910s. John Gibson Paton's son, Frank, continued his father's efforts as a leading figure in the church at this time, though his attitude to the labour trade and French influence in the Pacific was more moderate. He published several books and pamphlets, and in 1923, he led a public campaign in Australia to end the condominium. Although they did not achieve the desired outcome, the Presbyterians did have some success; they supplied

58 Australasian New Hebrides Company, Australia and the New Hebrides, 5.

59 Thomas, Cannibals and Convicts, 182.

60 Gaggin, Among the Man-Eaters, 116. 
evidence to British authorities, which was used in negotiations during the Anglo-French conference of $1914 .{ }^{61}$ Their strength lay not only with their influence in Australian politics but also in their sustained publishing work that brought news from missions to Australia with regularity and that maintained a clear and consistent message.

Mission accounts of the New Hebrides were generally influenced by the competitive nature of French and British missions in the Pacific Islands. This conflict was observed by travellers like Frank Coffee, who argued that there was 'more friction' between missions in the New Hebrides than in any other group. ${ }^{62}$ In the race to convert souls, British Protestants had reached the Pacific over 40 years before French Catholics had. In the New Hebrides, specifically, Protestants had firmly established themselves since the first LMS ministers had arrived in the late 1830s. They were followed by the Presbyterians and the Anglican Melanesian Mission, who sent European pastors, as well as Islander preachers, who were responsible for rapidly evangelising the region. By the 1880s, the Presbyterian Church was influential in the southern New Hebrides and the Melanesian Mission in the north. ${ }^{63}$ In contrast, the French Catholic missions (namely the Marists) had limited success in the Island group, failing to establish a base in 1848 and again in 1886. Instead, Sydney was the initial headquarters for the French Marist missions in the Pacific. Although the Catholics were dominant in New Caledonia, it was not until the 1900s that they made some headway in the New Hebrides, eventually increasing to a third of the Island group's population. The success of the Catholic missions in New Caledonia and the New Hebrides depended on support from the French government. ${ }^{64}$ The fact that Presbyterian and Catholic missions drew on congregations throughout Australia for financial and moral support further complicated matters politically. While the Presbyterian Church in Victoria actively lobbied against the French, Catholic communities in Sydney supported the French missions in the Pacific. However, the religious affiliations of individual Australians did not always align with his or her commercial or political motivations.

61 David Hilliard, God's Gentlemen: A History of the Melanesian Mission, 1849-1942 (St Lucia: University of Queensland Press, 1978), 240.

62 Coffee, Forty Years on the Pacific, 104.

63 Garrett, To Live Among the Stars, 294. See also David Hilliard, 'The South Sea Evangelical Mission in the Solomon Islands: The Foundation Years', The Journal of Pacific History 4, no. 1 (1969): 41-64, doi.org/10.1080/00223346908572145; Clive Moore, 'Peter Abu'ofa and the Founding of the South Sea Evangelical Mission in the Solomon Islands, 1894-1904', The Journal of Pacific History 48, no. 1 (2013): 23-42, doi.org/10.1080/00223344.2012.756162.

64 Aldrich, The French Presence in the South Pacific, 36-8. 
In official Australian mission accounts, the condominium was portrayed as being a threat to missionaries' ability to civilise and Christianise, which they often framed within a nationalistic discourse. Missionaries were represented as champions of Australia, of traders and of Islanders, similar to the way that BP had branded itself to serve its own ends. Frank Paton's Glimpses of the New Hebrides is one such example. Describing his visit to the Island group in 1913 for a Presbyterian Synod meeting, Paton praised the work of the missions and described the problems that were associated with the condominium arrangement. When visiting the court to watch a trial, he was critical of the hostile French judge:

Judge Colonna was a keen-looking Frenchman-the author of the famous anti-missionary speech that called forth strong but vain protests against his elevation to a seat on the Joint Court Bench. His appointment is regarded on the British side as an absolute scandal, yet the British Government felt utterly helpless to prevent it. ${ }^{65}$

Paton also provided a summary of the Synod's report, which stressed the mission's struggle against French opposition:

The attitude of the French continues to be hostile. Their opposition to the work of the Mission, their policy of encouragement of heathenism, and the active interference with native Christians, constitute one of our most serious difficulties, and militates against the progress of the Gospel throughout the Group wherever French influence is felt. It is not only with regard to Mission work that difficulty is felt, but the general welfare of the New Hebrides is imperilled. ${ }^{66}$

Like many other mission accounts, Paton positioned missionaries as guardians of justice for British subjects and framed the condominium as a threat to British Christian morals. Using the example of an imprisoned Islander pastor, Paton portrayed French rule as a 'brutal oppression and cynical injustice', and then called for the restoration of 'justice and mercy'. ${ }^{67}$

65 Frank Hume Lyall Paton, Glimpses of the New Hebrides (Melbourne: Foreign Missions Committee, Presbyterian Church of Victoria, 1913), 15.

66 Paton, Glimpses of the New Hebrides, 47.

67 Paton, Glimpses of the New Hebrides, 93-4. 
Resonating with calls for British or Australian rule that would restore order and 'civilise the savage', other travellers repeated Paton's moralising tone. Government agent Douglas Rannie portrayed the New Hebrides in a 'wild, uncivilised state', with 'many fearful acts of lawlessness' occurring 'under the influence of liquor, and the smell of gunpowder'. ${ }^{68}$ The supposed degradation and depopulation of Pacific Islanders were also used to prove the failure of the condominium. In Grimshaw's perspective, the 'utter barbarism' that she observed among the Islanders served to strengthen her argument for strong British rule in the New Hebrides:

At present, the islands are in the most uncomfortable and unsettled state it is possible to conceive. There is no other place in the world where an uncivilised coloured race is to be found in an entirely self-ruling condition, owning no real master, and not even 'protected' by any of the great Powers. ${ }^{69}$

Due to the temporary nature of their visits, Australian travellers to the New Hebrides rarely observed the nuances of conflicts between Christian denominations and between individual missionaries, government officials and traders. Missionaries were entangled in complex networks of exchange in the Islands-and they were not always directly opposed to traders and commerce. Rather, they relied on shipping for the transportation of goods and competed with one another in offering shipping subsidies. Co-lobbying proved effective when mission and business interests were aligned, as was demonstrated when Presbyterian missionaries passed a resolution in 1890 that opposed British restrictions on inter-island labour recruits. ${ }^{70}$ Missionaries also supported new arrivals from Australia by acting as guides for tourists or by helping settlers adjust to their location, as Presbyterian missionaries had done for the Australian settlers who joined the BP settler scheme in $1902 .{ }^{71}$ Similarly, traders and planters also helped new missionaries adjust to their environs. In light of these complex relationships, many travellers were uncertain whether missionaries were responsible for assisting or for hampering the development of the Islanders and local businesses, or for the functioning of the condominium. Travel impressions were glancing, and in their reflective

68 Douglas Rannie, Notes on the New Hebrides (Brisbane: Royal Geographical Society of Australasia, 1890), 9, 28.

69 Grimshaw, From Fiji to the Cannibal Islands, 178.

70 Buckley and Klugman, The History of Burns Philp, 62.

71 Buckley and Klugman, The History of Burns Philp, 101. 
narratives, Australians tended to prefer the stereotype of missionaries as being saints or sinners. Marshall remarked on this practice in 1937, while in the New Hebrides:

It is customary to condemn the missionary. Every tropic traveller has met individuals who find a perverted type of pleasure in destructively, often maliciously, criticizing missionaries and their work. Both whites and natives in tropical regions are inveterate gossips and the unfortunate missionary runs the full gauntlet. ${ }^{72}$

Rather than clarifying the workings of the condominium in the New Hebrides, Australian travel writing generally contributed to confusion and speculation about what was commonly termed the 'pandemonium'. By 1914, Australian public interest in the New Hebrides decreased as French settlement and commerce outpaced Australian and British efforts, along with the advent of World War I, which shifted attention away from the French towards German aggressors instead. Although support for, and interest in, the New Hebrides' annexation continued to surface in the following decades, public hostility directed towards French dominance in the group was not as fierce as before. ${ }^{73}$ In light of this general atmosphere of confusion, Australian travel writers were just as likely to direct their criticism at British apathy as they were to French imperial designs. For many who advocated the moral duty of the Empire, British inaction had proven to be the most difficult to reconcile. Grimshaw used a metaphor of a runaway horse to describe the situation and to stress the need for strong leadership in the region:

And I wished, most earnestly, that I could see the strong hand of Great Britain or her Colonies grasp the bridle of this wretched country, as unfit to be left to its own guidance as any runaway horse, and pull it firmly and determinedly into the road of civilisation and law-abiding peace. ${ }^{74}$

Others, like John Henry Macartney Abbott, were more ambiguous:

Here, in the very essentials of the process of civilization, we find influences brought to bear upon the native that are utterly unlike, if not to a certain degree hostile to, one another. It would be strange if some small amount of chaos did not manifest itself in these earlier stages. ${ }^{75}$

72 Marshall, The Black Musketeers, 310.

73 Thompson, Australian Imperialism in the Pacific, 198.

74 Grimshaw, From Fiji to the Cannibal Islands, 305.

75 Abbott, The South Seas (Melanesia), 29. 
Although the New Hebrides may have been considered unstable and residing in a period of transition in the early twentieth century, travel writing about New Caledonia by contrast highlights the Island's transformation into a tourist destination.

\section{From Detractions to Attractions in New Caledonia}

As opposed to the accounts of the late nineteenth century that criticised French colonial rule and penal settlement in New Caledonia, travellers of the twentieth century increasingly identified the Island group as a tourist destination that was considered exotic, safe, close to home and cheap. New Caledonia's main attractions were commonly identified as its convict heritage and the exoticness of its French culture. Dying of asthma in Melbourne in 1896, one year before the end of penal settlement in New Caledonia, James's concerns for the threat that the colony posed to the Australian mainland were no longer shared by travellers of the 1900s. Meteorologist Clement Lindley Wragge was typical of these new visitors. He was one of five Australians identified in this study who wrote travel accounts of New Caledonia that were published between 1900 and 1914 . An additional seven travel accounts were written by Australians from 1914 to 1941 . Of these writers, Wragge travelled the most extensively through New Caledonia, and he wrote down his impressions in the greatest detail.

Born in England in 1852, Wragge ran away from home as a teenager, with his travels bringing him to Australia in 1874. Appointed to the surveyorgeneral's department in South Australia in 1876, he married a year later and studied meteorology. In 1878, Wragge travelled to Britain for three years to establish weather observatories. After returning to Australia in 1883, he continued to establish meteorological stations across the country, so he could try and predict and observe weather patterns. During this time, Wragge helped found the Royal Meteorological Society of Australia and was appointed Chief Meteorologist for Queensland (1887). He resigned from his Australian post and moved to Dunedin, New Zealand, in 1903, where he published his travelogue, gave lecture tours and raised a family until his death in 1922.

Wragge's travelogue, The Romance of the South Seas, was based on his travels to New Caledonia in c. 1893 to establish a meteorological observatory, which coincided with the connection of the Noumea-Queensland cable. 
This allowed for the expansion of Wragge's meteorological observation and research network. As such, his impressions straddle two decades before and after the Australian Federation. Although he was travelling as part of a scientific mission, Wragge explicitly chose to not write as 'some cold official or scientist..$^{76}$ In fact, the second part of his book about Tahiti was styled as a travel guide. He was also loyal to 'our Empire', referring to England as 'home'. However, Wragge did adopt some Australian customs, frequently referencing Australian places and idioms and often wishing that Australia had annexed New Caledonia for itself. He concluded his journey with the statement: 'Farewell, New Caledonia! ... we wish you could join the Commonwealth of a free Australia! ${ }^{77}$ Although Wragge was loyal to British concerns, he was sympathetic to the French colonisers, describing them as 'a grand and noble people' who were supportive of his scientific mission. Wragge was also much kinder than James in his assessment of the French and of their attitudes towards Kanaks, noting that 'we agree with them in all but the treatment of prisoners. ${ }^{78}$ Unsurprisingly, not everyone shared this opinion: writing in 1901, Cheeseman focused on the potential danger that the French still posed, describing a harbour that could fit an entire French fleet, with forts and sentries everywhere, as well as hostile officials who scrutinised his every move. ${ }^{79}$

From the beginning, Wragge's fascination was focused on convicts. He called New Caledonia 'the Prison of the Pacific' and wrote that 'the convict element' was 'very strong', which was similar to James's observations 20 years before. ${ }^{80}$ Like other travellers, Wragge was aware of New Caledonia's past before arriving in Noumea, noting in his introduction that:

We knew full well of those miserable escapés who braved the seas and sharks in open boats, with parched throats and skeleton frames, just to reach fair Queensland-only to be interned there as suspects and undesirable vagrants. ${ }^{81}$

In 1903, George Phillips also empathised with escaped convicts, whom he argued 'merely sought Australia as a stepping stone for the purpose. Poor fellows! ... These men are not all bad'. ${ }^{82}$ These empathetic comments

76 Wragge, The Romance of the South Seas, 10.

77 Wragge, The Romance of the South Seas, 113-14.

78 Wragge, The Romance of the South Seas, 35-6.

79 Cheeseman, The South Sea Islands, 4.

80 Wragge, The Romance of the South Seas, 20; Thomas, Cannibals and Convicts, 117.

81 Wragge, The Romance of the South Seas, 4.

82 George Phillips, Notes on a Visit to New Caledonia (Brisbane: Brisbane Telegraph, 1903), 10. 
suggest that popular colonial Australian attitudes of the previous two decades had shifted away from negative and threatening representations, especially since the transportation of convicts had ceased in 1897 .

After arriving at Noumea, ships would pass Île Nou, the small island at the entrance to the harbour, where the main prison was located. 'That terrible islet of misery and degradation' wrote Wragge, when he recalled observing the convicts through his binoculars. ${ }^{83}$ From this initial reminder, travellers would then encounter convicts in the port and town. The chance of meeting a convict was high, with convicts and emancipists outnumbering free settlers until the early 1900s. In 1897, 22,315 convicts had been transported to New Caledonia, and by 1902, emancipists comprised 50 per cent of the Island's white population. ${ }^{84}$ Wragge observed 'a gang of doomed condamnés' building new wharves as soon as he arrived, and Phillips was fascinated that prisoners who worked on the roads were only lightly guarded and unshackled. ${ }^{85}$ Of even greater interest to travellers was the idea that ex-convicts could be hidden within the population, as Wragge had described his surprise when he met two libérés in Noumea who were disguised as a French gentleman and a priest. ${ }^{86}$

The most famous attraction in Noumea was the Place des Cocotiers (Coconut Square), with its chief attraction being the convict band that played there. Wragge described the weekly concerts as 'sublime'; he was impressed by their 'God-like' harmony and 'chords of Love', but his applause was quelled by French authorities who did not think his appreciation was appropriate. ${ }^{87}$ New South Wales politician John Charles Lucas Fitzpatrick was more entertained by the 'bizarre' group of people intermixing in the square, in close proximity with the criminals on stage:

I can promise you a scene, which, of its kind, cannot perhaps be equalled in any part of the world. Here come the white-uniformed bandsmen, escorted by their officer ... loud-laughing groups of buxom Loyalty Island girls ... natives of both sexes, from the New Hebrides ... a few, only a few New Caledonians ... Solomon Islanders, and in fact, representatives of every group in the South Pacific. ${ }^{88}$

83 Wragge, The Romance of the South Seas, 15.

84 Merle, 'The Trials and Tribulations of the Emancipists', 40.

85 Wragge, The Romance of the South Seas, 113-14; Phillips, Notes on a Visit to New Caledonia, 9.

86 Wragge, The Romance of the South Seas, 39-40.

87 Wragge, The Romance of the South Seas, 24-5.

88 John Charles Lucas Fitzpatrick, Notes on a Trip to New Caledonia and Fiji (Windsor: Hawkesbury Herald, 1908), 42-3. 
Wragge, like other Australian travellers, repeated the popular myth that the band's conductor reportedly had killed his wife's lover and had fed her his heart for breakfast. ${ }^{89}$ This legend highlights the transfer of popular Melanesian tropes onto the convict population, as well as the beginnings of a tourist industry in New Caledonia.

For tourists who were searching for convicts, the prison on Île Nou was most easily accessible from Noumea by boat; it was more well known than any other camps. The prison on Île des Pins (Isle of Pines) was also infamous, but it was more difficult to access and had closed in 1890 . With permission from the Minister of Penitentiaries, Wragge visited Île Nou and described it as a 'place of utter doom and the blankest despair', likening it to a 'living hell', in which 'the clanking of chains resounds from yonder, the agonies of the condemned seem wafted on the air'.$^{90}$ Wragge witnessed an execution with the 'ghastly' guillotine, visiting the prison cells and the cemetery and watching the labour gangs at work. Alarmed, he wrote that 'the French penal system is demoralizing. It does not bring out the best in man. Au contraire, it degrades him and makes him worse' ${ }^{91}$ His experience of Île Nou was similar to James's experience 20 years before. James had also visited the prisoners, including a 19-yearold boy who was sentenced to death for trying to escape-a sentence that the author judged to be 'a hard lot'. ${ }^{92}$

Wragge's experience of Île Nou was repeated during his visits to a prison in Bourail and in Camp Brun. He explored the prisons in depth, taking notes on the male and female quarters, conducting interviews with officials, missionaries and prisoners, and making detailed descriptions of the prisoners' living conditions:

All the others appear utterly dejected and heart-broken, living but yet dead, hoping in very hope gone for that rest that should lead not to hell fire, but to eternal progress. ${ }^{93}$

89 Wragge, The Romance of the South Seas, 25; George Wirth, Round the World with a Circus: Memories of Trials, Triumphs and Tribulations (Melbourne: Troedel \& Cooper, 1925), 39; Matsuda, Empire of Love, 113.

90 Wragge, The Romance of the South Seas, 90, 92.

91 Wragge, The Romance of the South Seas, 94.

92 Thomas, Cannibals and Convicts, 119.

93 Wragge, The Romance of the South Seas, 63. 


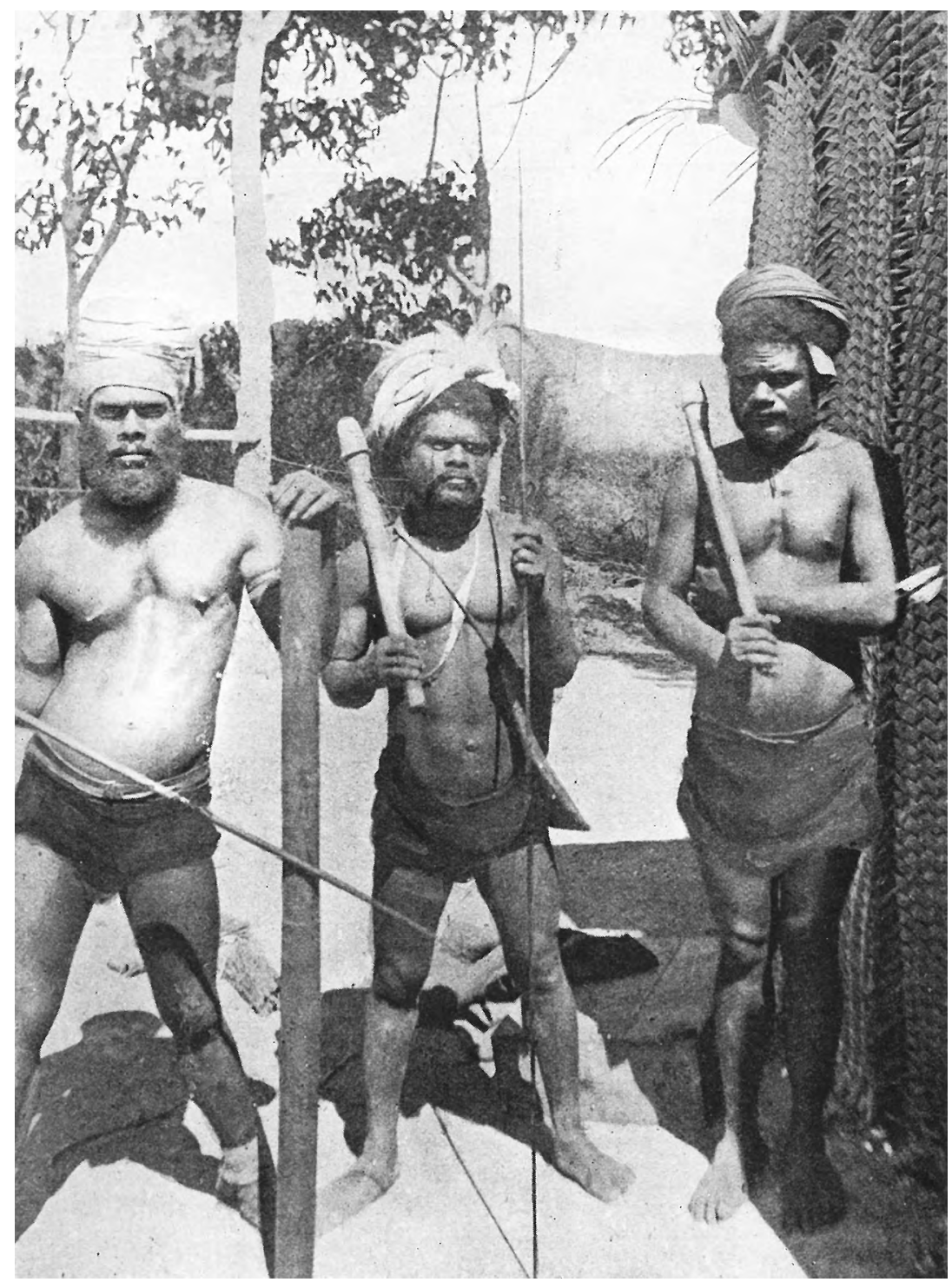

Figure 18: Canaques Are After Them.

Source: Wragge, The Romance of the South Seas, 81.

He took several photographs of the prisons, which he used to illustrate his book, along with ethnographic portraits of Kanak men (see Figure 18; the men in this image likely worked in the prison). Although Wragge's account of the harshness of French rule shared similarities with James's 
earlier reports, his view was not shared by all travellers of the early 1900s. Phillips's views challenged the notion that the French prison life was horrible and credited the penal system with producing fine public works. ${ }^{94}$ Other travellers did not encounter the realities of imprisonment face to face because the system was already in the process of dismantlement.

Wragge's empathy with the local convicts may have been motivated by his witnessing of the cruelty of the penal system firsthand. In fact, he explicitly stated that the subsequent experience during residence and travel in the island did but tend to strengthen a sympathy in their favour, as will duly appear'. ${ }^{95}$ However, his response may also signpost a broader Australian colonial sympathy with French prisoners, based on a shared convict heritage. Peter Kirkpatrick argued that the Australian Bohemian community in Sydney embraced French customs and habits because it was an alternative to conservative British values, with notions about France as 'the land of revolution and democratic hope' resonating with their political ideology. ${ }^{96}$ This can be evidenced in certain newspaper articles, such as the one in the Sydney Morning Herald in 1888, which described escaped French convicts as 'bushrangers'. ${ }^{97}$

Although French convicts prompted numerous empathetic and hostile responses in Australian society, it was a particular group known as the communards who generated a generally positive public response. The communards were 7,000 political prisoners who were transported to New Caledonia in 1872 for their role in the 'Paris Commune', which revolted against the French government in 1871 . The close proximity of these political prisoners was initially a concern of Australian authorities due to the revolutionary ideas that they represented. However, the potential threat diminished over time, especially after they were pardoned in $1879 .{ }^{98}$ As Bergantz revealed, the Australian media frequently downplayed the crimes of the communards, with the aim of distancing colonists from their own convict pasts and distinguishing them from the recidivist who was portrayed as the true criminal. When convenient,

94 Phillips, Notes on a Visit to New Caledonia, 2.

95 Wragge, The Romance of the South Seas, 17.

96 Kirkpatrick, The Sea Coast of Bohemia, 32.

97 'Escaped Convicts in New Caledonia', Sydney Morning Herald, 27 November 1888, 4, nla.gov. au/nla.news-article13704947.

98 Aldrich, The French Presence in the South Pacific, 225. 
communards were alternatively used as scapegoats or as heroes for political purposes in Australia. ${ }^{99}$ As one writer explained in a fictional piece in The Clipper in 1905:

The word 'communard' has two different meanings. According to some he is a social leper, who despises everything good and revels in all things evil ... But there are those who suffered from their connection with the Commune of $1871 \ldots$ who were fighting for a principle, and who were proud to die in the cause of freedom and justice. ${ }^{100}$

One communard, French journalist Henri Rochefort, was notable in this public debate, having escaped to Australia in 1874 . He was widely portrayed as a hero in the Australian press and by James, long after the communards were released. ${ }^{101}$ Even in the 1900s, travellers to New Caledonia were aware of the communard story. Their imprisonment and release had become symbolic of the heroism and resilience of French convicts. In 1941, Australian journalist Wilfred Burchett still referenced the communard legacy: 'The Communards in New Caledonia ... have helped to establish a new tradition of liberty and tolerance'. ${ }^{102}$

The communard story was part of a larger narrative of emancipation that fascinated Australian travellers. Just as Australians had 'grown up' from their convict origins, so too were libérés commencing their own new lives. Empathising with the 'poor libéré who has atoned for his sins', Wragge noted:

With us it is not so. A man convicted; well! He atones and pays for his mistake, be it twenty years and may rise again. But to climb under French jurisdiction to a once-held position in free society is practically impossible. ${ }^{103}$

This is consistent with the romanticisation of the liberé as being the 'archetypal vagabond' in early colonial literature-a figure that remained a preoccupation for free residents of New Caledonia until the 1920s. ${ }^{104}$

99 Bergantz, 'French Connection', 77-85.

100 J Sinclair Tayler, 'The Isle of Submarines: A South Sea Terror', The Clipper, 14 October 1905, 4.

101 For example, see 'A Famous Communard: The Adventurous Career of Louise Michel', The Mercury,

27 March 1905, 7; 'Personalities: Henri Rochefort', Windsor and Richmond Gazette, 24 August 1889,

12; Thomas, Cannibals and Convicts, 127.

102 Burchett, Pacific Treasure Island, 122.

103 Wragge, The Romance of the South Seas, 36-7.

104 Muckle, Specters of Violence, 7. 
Consequently, Australian visitors were eager to seek them out. William Ramsay Smith was one such traveller who, in 1924, photographed two libérés living in a cave. ${ }^{105}$

Another element contributing to the Australian fascination with French convicts was their growing popularity as a tourist attraction. This included the prison buildings and the convicts themselves. Wragge's account suggests that he was motivated by a subversive desire to visit the prisons. An avid collector, Wragge took unusual souvenirs from the prisons, including the wings of a bird that a prison guard had killed in a solitary confinement cell and the stuffing from a woman's prison mattress. Despite recording the horrors of the prison system, including documenting an execution in gruesome detail, Wragge appeared not to be heavily affected by the scenes that he had witnessed. Returning to his hotel after visiting the prison, he casually remarked, 'Ah well! Such is an experience of human life'. ${ }^{106}$ His behaviour may reflect a broader trend of 'dark tourism' that involves visiting sites associated with death and tragedy. ${ }^{107}$ It also resonates with the behaviour of Australian tourists who visited prisons in Australia in the early twentieth century. As Richard White demonstrated, these tourists were eager to visit historic convict sites such as Port Arthur, and even re-enacted scenes of torture or execution. This was despite, or perhaps in reaction to, official efforts to restrict access to these sites due to shame regarding Australia's convict past and the denial of its convict ancestry. ${ }^{108}$

The convict element remained a lucrative attraction in the 1920s and 1930s, despite the cessation of convict transportation to New Caledonia in 1897 and the closure of penal settlements there by 1922. The sense of danger or violence had disappeared, yet tourists still recounted second-hand stories and reported hearsay about past prisoners and brutality. Although the Coconut Square's convict band was disbanded, a group still played there and attracted a large crowd by 1941, with Burchett observing that 'a treasure-house of interesting characters whose stories, pieced together, would compile a voluminous and colourful history'. ${ }^{109}$ Burchett sought out and paid ex-convicts for interviews, many of whom were poor or homeless:

105 Smith, In Southern Seas, 19.

106 Wragge, The Romance of the South Seas, 70, 96.

107 Nicholas Halter, “'Cannibals and Convicts": Australian Travel Writing about New Caledonia', in The Palgrave Handbook of Prison Tourism, ed. Jacqueline Z Wilson, Sarah Hodgkinson, Justin Piché and Kevin Walby (London: Palgrave Macmillan, 2017), 867-84, doi.org/10.1057/978-1-13756135-0_41.

108 White, 'The Subversive Tourist'.

109 Burchett, Pacific Treasure Island, 104. 
There are not many of the old convicts left now ... most of them are well-known characters and can always rely on a few francs a day from former employers or workmates. ${ }^{110}$

His efforts produced mixed results. Henri Tartas offered an interesting story of escape and intrigue, while Quer Urbain's story was 'dreary rather than exciting', with 'much rambling and many repetitions'. ${ }^{111}$ Even the sublime charm of the prisons had been lost, as the buildings were re-used for alternative purposes:

To-day Ile Nou has been converted by Pan American Airways into a modern air base ... Ile des Pins, where most of the Communards were imprisoned, is a charming island visited by young couples on their honeymoon, and once or twice a year the object of a specially organized tourist excursion from the mainland. The Peninsula Ducos, the site of the third main penitentiary hasn't had as happy a fate as the other two-it now houses New Caledonia's leper colony. ${ }^{12}$

For these reasons, Burchett recommended to his readers that they visit French Guiana or read other books to experience the French penal system.

In addition to its historic convict attractions, French culture was becoming identified by Australians increasingly as an admirable and attractive characteristic of the colony in the 1900s. These features pushed the island's Pacific characteristics into the background. Burchett remarked that:

Added to the delights of living French, eating and drinking French, hearing and speaking French, is the attraction that in New Caledonia all these things can be enjoyed in the most perfect South Sea background. ${ }^{113}$

French culture, fashion and food were popular in Australia at the turn of the century and were considered symbolic of high art, culture and modernity. ${ }^{114}$ It is thus unsurprising that visitors to New Caledonia described their daily routine in vivid detail, as they relished French food and drinks and enjoyed the novelty of reading French menus and street names. Fitzpatrick's description of the daily practice of midday siestas was

110 Burchett, Pacific Treasure Island, 101-2.

111 Burchett, Pacific Treasure Island, 93, 101-2.

112 Burchett, Pacific Treasure Island, 100.

113 Burchett, Pacific Treasure Island, 20.

114 Bergantz, 'French Connection', 43. 
common in travel accounts, and he enjoyed the choice of cafes and bars in Noumea. ${ }^{115}$ Phillips also admired French dining habits, noting that 'a French breakfast is a very serious undertaking ... but remember that one French meal is equal to two English ones'. ${ }^{116}$

Favourable descriptions of French culture were accompanied by an admiration of French sensibilities. Wragge was explicit in his admiration of the French, describing them as 'a grand and noble people' who were 'liberal and broad-minded'; he argued that 'France can teach us to live in the pure enjoyment of life'. ${ }^{117}$ James, writing much earlier, had acknowledged that "France is lovingly known by her sons as the country "la belle" par excellence. And she deserves the title'. ${ }^{118}$ In Burchett's case, his admiration of the French was expressed with reference to the nation's convict past: 'Because the Old World rejected—or ejected—many of the finest spirits of the age, the New World bordering the Pacific has a virile, liberty-loving ancestry'. ${ }^{119}$ Others felt an affinity with the French because they shared a common European civilisation. James expressed this sentiment when he wrote about the New Hebrides: 'White blood is thicker than water, and Englishman and Frenchman are akin when brought face to face with savages'. ${ }^{120}$

Travellers also noted the influence of French colonialism, enjoying the architecture and modern advancements. Many commented on the adequate water and sewerage systems, clean streets, electric lighting, suitable roads and impressive buildings such as churches, government offices, restaurants and hotels. In 1912, Rannie remarked:

The hotels are good and the tariff uncommonly moderate. I had a bedroom and sitting-room to myself, and an excellent table, for the moderate sum of ten francs per day in a first-class hotel. The town is beautifully laid out, and fine shade trees are planted along the streets. Most enjoyable drives can be had in all directions, as the roads are kept to perfection. ${ }^{121}$

115 Fitzpatrick, Notes on a Trip to New Caledonia and Fiji, 45.

116 Phillips, Notes on a Visit to New Caledonia, 3.

117 Wragge, The Romance of the South Seas, 36.

118 Thomas, Cannibals and Convicts, 49.

119 Burchett, Pacific Treasure Island, 122.

120 Thomas, Cannibals and Convicts, 162-3.

121 Rannie, My Adventures among South Sea Cannibals, 242. 


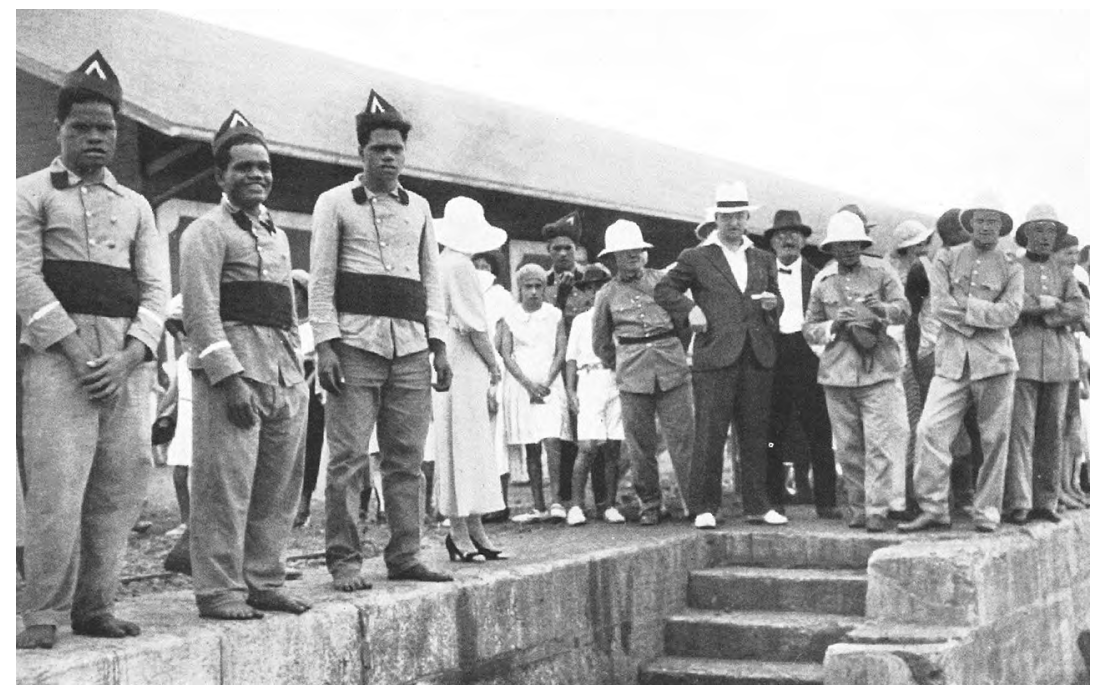

Figure 19: On the Quayside, Noumea.

Source: Stephen Henty, 'New Caledonia', Walkabout (November 1935): 29, 31. Image courtesy of the Australian National Travel Association.

These observations reflect the pace at which French colonial officials were developing the colony, with the help of convict and foreign labour. New Caledonia's importance as a penal settlement and the growth of its mining industry signified that it was much more developed and populated by the French than the isolated Islands of French Polynesia. Photographs of New Caledonia taken by travellers frequently included images of the indigenous police forces, who were regarded as a sign of progress, development and law and order (see Figure 19). This also reinforced a message of successful French colonialism when, in fact, Kanak resistance continued in the early twentieth century. Images of the police were not an exclusive feature to New Caledonia, but their prevalence in travel accounts is more noticeable than in other Islands in the Pacific. They should thus be considered within a broader context in which Australians imagined the Island as a space of conflict and convicts since the mid to late 1800 s.

Travellers could visit more parts of the mainland by car, as the French extended their network of roads. George Meudell, another steamer tourist, commented on the prospects for a day trip by car: 'Noumea is a delightful centre for a holiday. There are two good hotels, excellent roads for motoring, and the scenery is right for motorists. ${ }^{122}$ This scenery was 
often noted for its European rather than Pacific characteristics. Travellers drew similarities between the niaouli tree and the Australian eucalyptus, as well as the lush hills of the mainland (and the cattle they supported), were compared to familiar European and Australian landscapes. ${ }^{123}$ Visitors also remarked on the prevalence of mining to a greater extent than in any other Pacific Island. These observations generally dominated Australian travel accounts, with limited descriptions of Kanaks. Visits to coffee or copra plantations warranted few comments about the labourers, instead focusing on their profitability or 'picturesque' qualities. Few also visited or commented about Kanak villages or mission stations. This suggests that as New Caledonia increasingly became marketed as a French holiday destination rather than as a Pacific reality, travellers were less inclined to report on its island characteristics.

\section{Fading from View}

From the beginning of World War I, Australian public interest in New Caledonia and the New Hebrides declined. The conflict in Europe had shown France to be an ally rather than an enemy, and the Australian government was preoccupied with the mandate for New Guinea that it had acquired in the aftermath. This decline was more pronounced in New Caledonia since Australian missionaries, businesses and residents continued to contest the condominium in the New Hebrides. Even a largescale Kanak rebellion in 1917 did not elicit the same response in Australia as the 1878 conflict had, presumably because it was overshadowed by news from the front in Europe. Max Quanchi has shown in his study of Australian illustrated magazines that New Caledonia went virtually 'unnoticed' by Australians during the interwar period. ${ }^{124}$ This was observed by Burchett when he visited in 1939 and 1941, noting that:

For many years this island has been but a name to most of us ... a name that featured once or twice a year as the goal of a tourist cruise to the South Seas ... [it] vaguely recalled the site of a particularly odious convict prison. ${ }^{125}$

123 Thomas, Cannibals and Convicts, 45; Burchett, Pacific Treasure Island, 20, 40.

124 Max Quanchi, 'A Name That Featured Once or Twice a Year: Not Noticing French New Caledonia in Mid-20th Century Australia', Journal of Pacific Studies 29, no. 2 (2004): 196.

125 Burchett, Pacific Treasure Island, 11. 
Australians still retained greater economic, religious and political interests in the New Hebrides than in New Caledonia, but economic investment in the Island group was diminishing and political will was intermittent. Australian travellers continued to describe the confusion that was created by the condominium in the 1940s, such as Woodburn, who described it as 'cumbersome, awkward, uneconomic and Gilbertian, but still existing.' ${ }^{126}$ Yet these travel accounts about the New Hebrides were not as prolific as those of other Pacific Islands. This may have reflected the slow development of tourist routes and infrastructure due to the condominium, or to the topography of the Island group, signifying that there were numerous ports of call and no particular site or attraction that appealed to Australian travellers. Although Vila did have some French characteristics to satisfy Australian tourists who sought the 'exotic', French culture and influence were less pronounced in the New Hebrides than it was in New Caledonia. These factors were visible in BP's advertisements of its cruises through the New Hebrides, which promoted the 'absorbing interest and changing scene' provided by 'over one hundred calls' that took the traveller 'quite out of the beaten track'. ${ }^{127} \mathrm{BP}$ also tended to focus on the potential for encounters with Melanesian inhabitants, rather than on an authentic experience of French food and culture. In fact, by 1925, BP's advertisements downplayed the condominium, remarking in one short sentence that the New Hebrides were of 'special interest as the theatre of a remarkable experiment in Government'. ${ }^{128}$ This starkly contrasted previous claims in 1903 that 'British supremacy [in the New Hebrides] ... is undoubted', a statement that was questionable by the 1920 s. ${ }^{129}$

BP's promotion of New Hebrideans as a tourist attraction contributed to essentialised and racialised stereotypes of the Melanesian savage that were repeated by Australian travellers. Abbott stated that 'a native of the group is a Melanesian before he is a New Hebridean'. ${ }^{130}$ Apart from these formulaic tropes, Islanders were frequently absent from travellers' descriptions of the condominium. Rather, they were commonly portrayed as a subjugated and silent people. Rannie believed that Islanders had 'no idea of what the annexation of their island means', and James doubted that they could

126 Woodburn, Backwash of Empire, 44.

127 Burns, Philp \& Company, Limited, Picturesque Travel, no. 5 (1925), 44.

128 Burns, Philp \& Company, Limited, Picturesque Travel, no. 5 (1925), 43.

129 Burns, Philp \& Company, Limited, All About Burns, Philp \& Company, Limited: Their Shipping Agencies, Branches and Steamers (Sydney: John Andrew \& Co., 1903), 106.

130 Abbott, The South Seas (Melanesia), 25. 
express their views, if they had any. ${ }^{131}$ This supposedly silent Islander was preferable in James's opinion: 'In Australia we have solved our native difficulty by never allowing that the blacks have any rights in the soil at all'. ${ }^{132}$ However, James was also willing to use them where necessary to support his criticisms of French rule. He claimed that every Islander disliked the French, and even overlooked the purportedly savage and childlike nature of New Hebrideans to emphasise the superiority of the British claim: 'They were not fools; they were bloodthirsty and brutal; but they had a sense of their own rights and their own liberties. ${ }^{133}$

The trope of the Melanesian savage was more often applied to the New Hebrideans than to the Kanaks, with the emphasis on French culture being extended at the expense of the Kanak population, about whom little is written. The Islanders who Australians most commonly met in Noumea were foreign workers, mostly drawn from the nearby Loyalty Islands and New Hebrides. Burchett described many 'boys' at the Noumea wharf who were waiting to carry passengers' bags but noted that they were Loyalty Islanders. Fitzpatrick listed the variety of nationalities in Coconut Square, to which he added, 'A few, only a few, New Caledonians'. ${ }^{134}$ This did not reflect the actual population, in which Kanaks outnumbered white residents. Other foreign labourers from Japan, Indochina, Réunion Island and Java also drew the gaze of Australian travellers away from the Kanak. The colony's development, particularly in regard to the mining industry, was built on cheap imported labour. In 1932, The Pacific Islands Yearbook reported statistics from the previous year that 6,198 Javanese and 5,026 Tonkinese labourers were part of a total population of $57,165 .{ }^{135}$ Travellers viewed the preference for foreign imported labour as the result of the innate laziness of the Melanesian, an observation that overlooked the role that Kanaks had played in the New Caledonian economy.

The omission of Kanaks in Australian travel accounts was symptomatic of a gradual process in which Kanaks were slowly isolated and marginalised over time by the French colonial administration. As a result of disease, warfare and violent encounters with French settlers and authorities, the Kanak population had been gradually forced into reserves. These were

131 Rannie, Notes on the New Hebrides, 6-7; Thomas, Cannibals and Convicts, 202.

132 Thomas, Cannibals and Convicts, 275.

133 Thomas, Cannibals and Convicts, 247.

134 Burchett, Pacific Treasure Island, 20, 184; Fitzpatrick, Notes on a Trip to New Caledonia and Fiji, 43.

135 Robson, The Pacific Islands Yearbook, 297. 
situated away from the major towns and urban areas, including the capital. ${ }^{136}$ In 1924, Smith observed these controls, noting that a "kanaka curfew' from 8 pm was in effect in Noumea. ${ }^{137}$ French control of the northern districts remained intermittent in the 1920s, and combined with the remoteness of some reserves, Australians were less inclined to move beyond Noumea to meet Kanaks. Those few Kanaks who Australians did encounter were usually given reductive descriptions that repeated Melanesian stereotypes-Burchett described 'negroid' physical features, claimed to discover cannibal 'feasting grounds' and met one Islander guide who was allegedly 'the perfect caricature of a missionary-filled cannibal'. ${ }^{138}$ Even in light of the French government's efforts to downplay past violent conflicts with Kanaks, Muckle argued that 'the idea of a recent savage past was too tempting to ignore altogether' in European literature, and recollections of past conflicts continued to label Kanak rebels as cannibals and savages from the 1920s to the 1940s. Australian travel accounts confirm a similar obsession with this 'trope of reawakened savagery'. ${ }^{139}$

In light of diminishing Australian public interest in New Caledonia and in the New Hebrides after World War I, it is unsurprising that generalisations about Melanesians in these Island groups persisted. Yet, given the historical relationship between Australia, these Islands and their colonial masters, it is remarkable that they could drift out of the Australian consciousness so rapidly. The historical legacy of French, British and Australian competition over these two Island groups before 1914 explains why Australian travel writing about New Caledonia and the New Hebrides was distinct from other Pacific Islands. New Caledonia was chiefly known for its convicts and its incidences of conflict between Europeans and Kanaks. These were issues of contention in Australia during the late nineteenth century until the early 1900s, when New Caledonia was transformed into a tourist destination; its convict heritage and French culture were becoming popular attractions. In the New Hebrides, Australian descriptions were marked by uncertainty and confusion, reflecting the controversial and contested nature of the Anglo-French condominium arrangement. Representations of both these Island groups were closely intertwined, and New Caledonia was frequently used as a device for justifying or criticising French control of the New Hebrides. Although popular opposition to French colonialism

136 Muckle, Specters of Violence, 5, 11.

137 Smith, In Southern Seas, 22.

138 Burchett, Pacific Treasure Island, 41, 64.

139 Muckle, Specters of Violence, 170. 
in these Islands was intermittent and temporary, they occurred at a crucial time in the development of the Australian nation. As such, these Islands were significant in shaping early Australian perceptions of the Pacific, and in providing a setting for Australian individuals, groups and governments to debate Australia's role in the region. 
This text is taken from Australian Travellers in the South Seas, by Nicholas Halter, published 2021 by ANU Press, The Australian National University, Canberra, Australia.

doi.org/10.22459/ATSS.2021.06 